\title{
eCOti
DiAno
}

Revista Mídia e Cotidiano

ISSN: 2178-602X

Artigo Seção Temática

Volume 14, Número 2, maio-ago. de 2020

Submetido em: 13/04/2020

Aprovado em: 17/05/2020

\section{Crítica do silêncio temático em Grande sertão: veredas - uma leitura de Diadorim ${ }^{1}$}

\section{A Critique to the silence that revolves around Grande sertão: veredas' themes - an interpretation of Diadorim}

\author{
Gustavo de CASTRO ${ }^{2}$ \\ Leandro BESSA ${ }^{3}$
}

\begin{abstract}
Resumo
Este artigo tem como objetivo discutir a ausência dos temas de gênero e da abjeção em Grande sertão: veredas (1956), de João Guimarães Rosa (1908-1967), por parte da crítica jornalística brasileira, com destaque especial à figura de Diadorim. Essa discussão ratifica a perspectiva de Silviano Santiago (2017) ao afirmar que o Grande sertão foi domesticado pelo pensamento conservador tanto acadêmico quanto jornalístico. Com uma metodologia de pesquisa bibliográfica e de arquivo de jornais, o artigo conclui que o não enfrentamento destas questões produz empobrecimento crítico.
\end{abstract}

Palavras-chave: Jornalismo. Literatura. Diadorim. Gênero. Guimarães Rosa.

\begin{abstract}
This article aims to discuss the absence of discussion of gender and abjection issues in João Guimarães Rosa's (1908-1967) “Grande sertão: veredas” (1956), by Brazilian journalism critics, with a special emphasis on the character of Diadorim. The discussion confirms Silviano Santiago's (2017) perspective, as this author states that the book "Grande sertão" was domesticated by the conservative thinking found in both the academic and journalism fields. Drawing from a methodological approach, based on a literature review and an analysis of newspaper archives, the article concludes that the lack of addressing gender and abjection issues results in impoverished critiques.
\end{abstract}

Keywords: Journalism. Literature. Diadorim. Gender. Guimarães Rosa.

\footnotetext{
${ }^{1}$ Este trabalho foi realizado com o apoio da Coordenação de Aperfeiçoamento de Pessoal de Nível Superior - Brasil (Capes) - Código de Financiamento 001.

2 Jornalista. Doutor em Antropologia. Professor de estética do Programa de Pós-Graduação em Comunicação da Universidade de Brasília. E-mail: gustavocastroesilva@gmail.com. ORCID: 00000001-7126-6947.

${ }^{3}$ Mestre em Comunicação pela UnB. Professor do Mestrado em Comunicação e Economia Criativa da Universidade Católica de Brasília (UCB). E-mail: lbessa.arte@gmail.com. ORCID: 0000-0003-48695887.
} 
Introdução

Em 2019, a editora Companhia das Letras lançou a 22a edição do Grande sertão: veredas em comemoração aos sessenta e três anos de publicação do único romance do escritor João Guimarães Rosa. Na ocasião, uma edição de luxo foi colocada à venda com número de exemplares igual aos anos comemorativos. A edição vinha com capa bordada à mão, contendo nomes dos personagens, que se inspirava no "Manto da apresentação" do artista Arthur Bispo do Rosário. O livro foi vendido por 1.119,00 reais e apresentado numa caixa de madeira de buriti. O projeto editorial selecionou, na seção de extras, duas cartas trocadas entre Fernando Sabino e Clarice Lispector, e textos da fortuna crítica literária, entre eles artigos de Roberto Schwarz, Walnice Galvão, Benedito Nunes, Davi Arrigucci Jr., e Silviano Santiago, além de uma cronologia da vida e obra do autor, sugestões de leitura e imagens de Guimarães Rosa.

A efeméride publicitária fez o livro voltar ao noticiário literário da imprensa brasileira, e esse retorno nos ajudou a problematizar a recepção da obra ao longo desses sessenta anos, a partir de temas reiteradamente silenciados. Serviu para compreendermos tanto o processo de reificação da obra como o posicionamento conservador, canônico e pouco crítico dado pelos jornalistas e articulistas em suas análises. Tal posicionamento reitera o que Silviano Santiago (2017) chamou de "domesticação"4 da face "monstruosa" do Grande sertão: veredas. Segundo ele, ao tratar do livro, a crítica literária brasileira "na sua vontade de dar continuidade ao já-lido" evitava certos temas. De certo modo, enjaulava o corpo indomável da obra.

Foi o que também verificamos ao observar algumas críticas produzidas a partir do relançamento da obra pela Cia. das Letras em 2019. Em três dessas análises colhidas aleatoriamente na imprensa por ocasião do reaparecimento do livro, temas como homossexualidade, demonologia, racismo, misoginia, entre outros, ficaram de fora do foco abordado. Os três textos por nós analisados foram os seguintes: o de Berthold Zilly

\footnotetext{
${ }^{4}$ Silviano Santiago desenvolve a noção de "domesticação" na obra Genealogia da ferocidade, de 2017. Para o autor, a "beleza selvagem" do Grande sertão: veredas obriga o crítico e estudioso da literatura brasileira a abrir mão do "já-lido" e repensar suas ferramentas de leitura que são, segundo Santiago, atreladas aos valores metropolitanos e eurocêntricos. A “qualidade selvagem” da obra de Guimarães Rosa está nos caracteres antimodernos das regiões coloniais, materializados na "intricada beleza monstruosa de obra sui generis" (SANTIAGO, 2017, p. 29).
} 
(2019), que publicou o artigo "Sertão de Guimarães Rosa pode ser visto como laboratório da condição humana", na seção Ilustrada do jornal Folha de S. Paulo; o de Milton Hatoum (2019), que publicou no jornal O Estado de S. Paulo, "Nova edição de 'Grande Sertão: Veredas' deve atrair e formar novos leitores"6, e, por fim, o de Lúcio Flávio (2019), do jornal eletrônico Metrópoles, de Brasília, que publicou "Grande Sertão: Veredas ganha reedição de luxo pela Cia das Letras""7.

Não seria possível abarcar a visão global e unificadora da crítica literária em Grande sertão: veredas, dada o tamanho de sua fortuna crítica, tampouco é o objetivo deste trabalho. No recorte apresentado, considerou-se, contudo, o alcance de público dos veículos e as suas análises de viés canônico/conservador. Nas três abordagens pouco se diz dos aspectos obscuros do romance. Os enfoques optam por valorizar temáticas gerais, alinhadas à clássica tradição literária. Verdadeira repetição da fortuna crítica já consolidada. Lançamos aqui a questão: não seria a obra de arte, por meio de sua ficção e imaginação, um modo de acessar o fantasma da realidade? Temáticas como a violência de gênero e homossexualidade, racismo, satanismo e a indeterminada, conflituosa e enigmática relação do autor com sua obra (considerando-se, sobretudo, o fato de Guimarães Rosa ter dado declarações polêmicas sobre alguns desses temas) são constantemente ignoradas pela crítica jornalística.

Entendemos que a crítica atua em parte atenuando os debates polêmicos. Tal "porteira" discursiva acaba por promover silenciamentos temáticos. No entanto, isto não é um fato recente. Em 1967, logo após a morte de Guimarães Rosa, o editor José Olympio organizou um gigantesco arquivo com mais de duzentas páginas de recortes de jornais publicados na imprensa brasileira sobre a vida e a obra do escritor mineiro. No arquivo, fica clara a extensão dessa domesticação. "Quem domestica estabelece um contrato desvantajoso para (ou pernicioso) com o que é selvagem" (SANTIAGO, 2017, p. 33). Em face essas problematizações, trataremos de discutir o tema da abjeção e a questão dos "saberes polêmicos" em Grande sertão: veredas para, em seguida, investigar aspectos de gênero com destaque especial à figura de Diadorim. Retornaremos aos recortes

\footnotetext{
${ }^{5}$ Disponível em: shorturl.at/AMW78. Acesso em: 06 abr. 2020.

${ }^{6}$ Disponível em: http://tiny.cc/88vdpz Acesso em: 06 abr. 2020.

${ }^{7}$ Disponível em: http://tiny.cc/g4vdpz. Acesso em: 06 abr. 2020.
} 


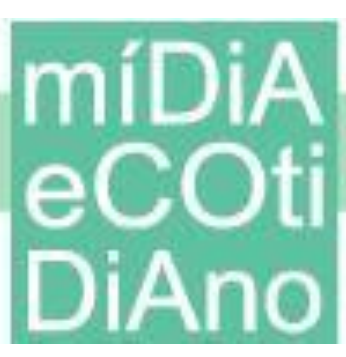

jornalísticos a fim de observar de que modo se dá a recusa da "realidade" abjeta da obra e, por conseguinte, de seu "silenciamento".

\section{A abjeção e a questão dos "saberes polêmicos"}

A noção da "domesticação" trazida por Santiago colocou em questão o modo como a obra foi recebida, associando-a a valores predominantes da cultura dominante, sobretudo aquela dos estudos comparatistas. Nossa hipótese é a de que a imprensa brasileira se recusa, não quer ou não sabe lidar com a temática da abjeção nas obras literárias. Esta hipótese foi anteriormente explorada por Vanessa Daniele de Moraes, no livro Passagens abjetas (2011), estudo sobre o tema em A Paixão Segundo G. H. (1964), de Clarice Lispector. De acordo com Moraes, o abjeto não diz respeito apenas ao que aparenta sujeira, mas ao que internamente surge como caótico, confuso, desordenado, semelhante ao estilo de composição narrativa adotada por Riobaldo ao contar sua história. Moraes resgata Bataille e Kristeva ao tentar entender como o abjeto aparece na literatura. Ao citar Pouvoirs de L'horreur - Essai sur l'Abjection (1980), de Julia Kristeva, ela identifica o abjeto como aquilo que perturba uma identidade, um sistema, uma ordem. É o que não respeita os limites, os lugares, as regras.

Segundo Moraes (2011), o conceito de abjeto engloba "a melancolia da perda", semelhante ao estado de espírito de Riobaldo ao descrever sua relação com Diadorim. Em sua obra, Kristeva adverte que, na abjeção, não há objeto definível: “Quando sou invadida pela abjeção, essa torção composta de afetos e pensamentos, que denomino assim, não possui propriamente nenhum objeto definível"» (KRISTEVA, 2004, p. 09).

De outra maneira, podemos dizer que uma parte temática de Grande sertão: veredas se inscreve naquilo que Peter Sloterdijk chamou de "Empiria negra" (2012, p. 340), ou seja, no campo dos "saberes polêmicos". Para Sloterdijk, é o fundamentalismo do pensamento o que faz nascer a empiria negra, aquela que se recusa a tratar dos temas marginais, insolentes, cruéis e demoníacos. Ao longo do tempo, os saberes polêmicos não

\footnotetext{
8 “Quand je suis envahie par l'abjection, cette torsade faite d'affects et de pensées que j'appelle ainsi, n'a pas à proprement parler d'objet définissable" (livre tradução dos autores).
} 


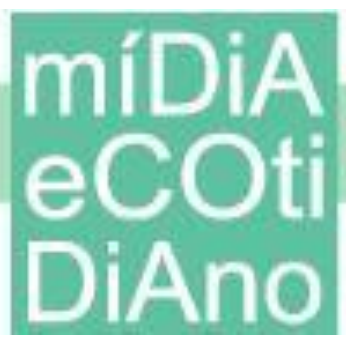

receberam a devida atenção por não serem considerados "nobres", "esclarecidos", "iluminados" e "confortáveis" ou mesmo devido ao pudor dos cientistas e pesquisadores.

Entre estes saberes está sem dúvida a questão do satanismo de Riobaldo. A nosso ver, a cultura cristã, fortemente influenciadora da sociedade brasileira ou mesmo daquela dos repórteres, articulistas e ensaístas, continua a interditar o tema. O satanismo de Riobaldo pode ser pensado ao lado dos saberes ligados à vingança e à traição, e os três são igualmente apagados nas análises. Some-se a isso o tema dos "de baixo", aqueles que estão à margem, “os condenados da terra”, como chamou Frantz Fanon (2018) em livro homônimo, originalmente publicado em 1961.

Vemos no romance de Guimarães Rosa o tema do puro e do impuro como arquétipos determinantes na visão de mundo de Riobaldo. Do mesmo modo, o tema da bipolaridade residual - o diabólico e o simbólico (Hermógenes e Diadorim), a poluição e a limpeza (as prostitutas e Otacília), o poder de destruição e o poder de regeneração (o Liso do Sussuarão e o sertão metafísico), os restos (os Catrumanos), o negro em associação ao diabo, a miséria e infância (o menino Guirigó). Além do satanismo de Riobaldo, temos a representação da maldade na personagem Hermógenes, nome que, sem dúvida, deriva de Hermes, por sua vez, hermético (sem asas nos pés) ou mercuriano (não filosófico, mas animado, regressivo, involuído), cujo discurso é convincente e cuja voz é perturbadora. No romance, ele é responsável pela morte do pai de Diadorim, que deseja, por conseguinte, a vingança.

Riobaldo apresenta Hermógenes da seguinte forma: "nasceu formado tigre, e assassim” (ROSA, 2015, p. 26), “... O Hermógenes tem pauta... Ele se quis com o Capiroto...” (2015, p. 51), “O Hermógenes - demônio. Sim só isto. Era ele mesmo.” (p. 61). A "pauta" de Hermógenes é pois aquela do mal. Desde o início do livro, o tema da vingança ou, mais precisamente, da ontologia positivada pela vingança, é representada, e não surge nas três críticas acima citadas, nem nas duzentas páginas de referências reunidas por José Olympio.

A vingança não é um ato arbitrário, mas é pensada e refletida. Do mesmo modo, a problemática do medo (que paralisa as decisões, tornando as pessoas sem caráter e inseguras), e a questão do ódio somam-se àquela da vingança. Assim, o que era uma vingança pessoal (de Diadorim) passa a ser coletiva (de vários bandos de jagunços, 


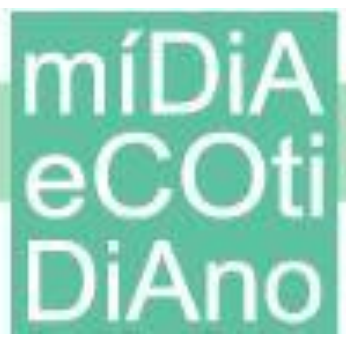

inclusive aquele comandado por Urutu-Branco/Riobaldo). A vingança ganha dimensões filosóficas e teológicas quando as forças do mal se enfrentam mutuamente. A questão metafísica colocada é a de como um pactário pode derrotar outro. Não se trata aqui do (clássico) tema do bem contra o mal, mas do mal versus o mal: Urutu-Branco/Riobaldo de um lado e Hermógenes do outro. Em um ciclo de aparições malignas, a atmosfera diabólica percorre a obra num movimento que vai da escuta de um disparo, e do nascimento de uma criança com cara de cachorro no início do livro, até as invocações de Riobaldo nas Veredas Mortas. Grande sertão: veredas é, do início ao fim, um texto que pode ser lido à luz do "infamiliar" e do "estranho" (1919), de Freud (noção que será retomada a seguir).

Entre os temas ligados aos "saberes polêmicos" daremos agora atenção particular à questão de gênero, especialmente à temática da sexualidade entre os personagens Riobaldo e Diadorim. Articulação analítica que problematiza uma das temáticas abjetas e que igualmente não receberam atenção ou prestígio por parte das três críticas analisadas.

\section{Diadorim: transgeneridade guerreira}

Como dissemos, Grande sertão: veredas toca os anátemas morais da tradicional sociedade brasileira. Além dos temas já citados, podemos acrescentar outros como a feitiçaria, o espiritismo, os abusos sexuais, a prostituição, a homofobia, a misoginia e a transgeneridade. Silviano Santiago entende que: "É preciso, pois, cuidado com o método, com a tática de abordagem dos objetos, em suma: com a estratégia de leitura dos textos afins" (SANTIAGO, 1982, p. 20). Para ele, as matrizes metodológicas de análise da obra são, em sua maioria, comparatistas, não que isso seja um problema, mas a dimensão do oculto continua a não ser abordada. As questões de gênero, por exemplo, não são frontalmente tratadas. Nos textos de jornais (Folha, Estadão e Metrópole), fica evidente o sintoma de repetição do bom mocismo crítico, efeito e sinal da "domesticação" assinalada por Santiago (2017).

Queremos destacar aqui o enfoque de gênero, numa perspectiva que coloca Diadorim como objeto central de nossa reflexão. Maria Deodorina é filha única do "grande homem príncipe", o chefe guerreiro Joca Ramiro, sem direito de conhecer sua 
mãe. Diadorim é uma espécie de Pallas Athenas brasileira ou, de uma perspectiva menos eurocêntrica, uma garota em perigo. Nascida numa sociedade patriarcal e misógina, isso significa que, para sobreviver no meio de uma cultura dominada pelas regras falocráticas, foi necessário que ela ${ }^{9}$ escondesse sua condição de mulher e assumisse modos masculinos.

Diadorim se veste de menino desde a sua infância, atenta aos conselhos de seu pai: "sou diferente de todo o mundo. Meu pai disse que eu careço de ser diferente, muito diferente..." (ROSA, 2015, p. 99), exclama o Menino/Diadorim com quatorze anos. Porém, a estrutura narrativa do romance não nos permite conhecer as intenções de Diadorim, a não ser pela voz do narrador-protagonista, Riobaldo. Isto é, o conflito sexual homoerótico é uma questão de Riobaldo e que o atormenta: "De Diadorim eu devia de conservar um nojo" (ROSA, 2015, p. 261). A ambiguidade expressa na quase abjeção de Riobaldo é o ponto de vista de seu conflito sexual. Não bastasse isso, o tema do "nojo" surge aqui de imediato.

Diadorim é para Riobaldo uma visão obtusa e incerta. Algo que se dá no próprio nome (Deus [deo] ou diabo [diá]). Marca que demonstra seu trânsito entre uma face luminosa e outra sombria. O nome de Diadorim é, portanto, indefinido e impregnado de ambiguidades, percebidas face ao conflito sexual de Riobaldo. Conflito decorrente do desejo privado por outro homem.

No entanto, a descoberta ulterior de que esse homem é um corpo de mulher ${ }^{10}$ não explica o desejo que sentiu antes, e, mesmo passados longos anos, Riobaldo se vê atraído e assombrado pela imagem de Diadorim enquanto homem. Isso nos leva a

\footnotetext{
${ }^{9} \mathrm{Na}$ perspectiva queer, o binarismo advindo da norma heterossexual não se aplica às categorias que rompem o modelo gay/lésbica, homossexual/heterossexual. De tal modo, o impasse no pronome de tratamento torna-se indiferente. Pela escrita inclusiva, diversas alternativas têm surgido (e/@/x). No entanto, para nós, o tratamento dado à Diadorim aceita tanto ele quando ela, pois enfrenta o mesmo dilema de Riobaldo: "tudo é e não é". Nesta discussão, concordamos que não cabe uma única possibilidade de escolha. O mesmo ocorre na voz de Riobaldo, mesmo consciente do sexo de Diadorim, continua a referirse a ele ao mesmo tempo que ela: "E, Diadorim, às vezes conheci que a saudade dele não me desse repouso; nem o nele imaginar. Porque eu, em tanto viver de tempo, tinha negado em mim aquele amor, e a amizade desde agora estava amarga falseada; e o amor, e a pessoa dela, mesma, ela tinha me negado (ROSA, 2015, p. 489, grifos nossos).

${ }^{10}$ Marcia Tiburi (2013), no seu artigo Diadorim: biopolítica e gênero na metafísica do sertão, entende que Diadorim foi duplamente assassinada, primeiro pela privação da sua condição mulher, fato que autoriza a sua permanência na vida pública (espaço masculino). Segundo, pela morte física (condição homo sacer), marca de um corpo morto objetificado: "Emblema da matabilidade da vida mera" (p. 201).
} 


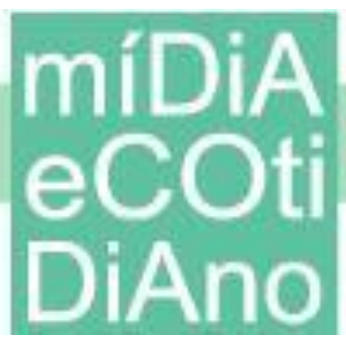

questionar: por que a crítica literária continua a definir Riobaldo como um homem heterossexual? Para o escritor chileno Daniel Balder (1999) ao menos deveríamos tratar a personagem com uma fluidez de sua orientação, uma espécie de bissexualidade, comum e relativa aos desejos ambíguos. No entanto, numa obra como Grande sertão: veredas, “[n]ão dá para falar sobre 'bissexualidade' ou orientação sexual: o desejo no Grande Sertão é tão fluido que não se deixa canalizar, que transborda os canais da orientação desejada" ${ }^{11}$ (BALDER, 1999, s/p).

Neste ponto, já seria possível sublinhar a dimensão do inquietante que percorre o conflito sentimental de Riobaldo, aquilo que Freud nomeou como "Unheimlich", isto é, um sentimento de estranha familiaridade, colocada em evidência por meio da narração - sensação de angústia pelo desconhecido. "[...] tudo o que deveria permanecer em segredo, escondido, mas que veio à tona" (FREUD, 2019, p. 43). No artigo "Riobaldo/Diadorim e o tema da homossexualidade", Vilalva destaca que Riobaldo, mesmo sabendo da "verdadeira identidade" de Maria Deodorina, opta por apresentá-la como jagunço: "Essa opção intensifica, no discurso, o tema da homossexualidade." (2008, p. 233).

Ora, Riobaldo se deixou amar por outro homem, afirmação que se verifica no próprio texto: "Diadorim - mesmo o bravo guerreiro - ele era para tanto carinho: minha repentina vontade era beijar aquele perfume no pescoço: a lá, aonde se acabava e remansava a dureza do queixo, do rosto... Beleza - o que é?” (ROSA, 2015, p. 467).

Fato é que a questão do preconceito homossexual, decorrente da escrita viril de Guimarães Rosa, encontra-se explicitamente no romance. Mesmo com os poucos estudos de gênero (ou de pouca projeção) à época da publicação do romance, Guimarães Rosa abordou a vontade sexual de um homem que cogitou amar outro homem, "Riobaldo enfrenta esta contradição: ele, um homem de mulheres, ama um homem, e sabe que ama um homem" (GALVÃO, 1986, p. 101).

Na perspectiva dos estudos de gênero, o desejo de Riobaldo pelo companheiro de luta e travessias não explica a categoria de gênero de Diadorim, que é ao mesmo tempo

\footnotetext{
11 "Ni siquiera se puede hablar realmente de 'bisexualidad', ni de orientación sexual: el deseo en Grande Sertão es tan fluido que no se deja canalizar, que se desborda de los cauces de una deseada orientación" (livre tradução dos autores).
} 
o Menino, Reinaldo e Maria Deodorina. Essa característica não categórica de caráter não determinista é o centro da questão nos debates queer: "Em teoria, queer está incessantemente em desacordo com o normal, a norma, seja a heterossexualidade dominante ou a identidade gay/lésbica. É categoricamente excêntrico, a-normal" (SPARGO, 2017, p. 33). Com isso, é possível desassociar o conflito sexual de Riobaldo — do ponto de vista do desejo homoerótico — da categoria de gênero de Diadorim ${ }^{12}$. Na perspectiva dos estudos queer essas são duas categorias distintas.

Em resposta à tese de filiação literária do padrão da “donzela-guerreira”, Helder Thiago Maia (2018) propõe queerizar a clássica leitura, isso é “contaminar a crítica literária com os estudos queer, especialmente, neste caso, mediante as considerações de Halberstam (2008) e Mauro Cabral (2006) sobre masculinidades” (MAIA, p. 99). Na proposta de queerização da donzela-guerreira, Maia identifica quatro expressões de gênero, significativamente distintas entre si, diferindo da crítica literária:

Entendemos, portanto, que nessa constelação literária das donzelas guerreias há: 'mulheres masculinas', personagens que não foram à guerra e nem viveram como homens; 'mulheres guerreiras', personagens que não viveram como homens, mas foram à guerra; 'donzelas-guerreiras', personagens que viveram como homens temporariamente, em segredo e foram à guerra; 'transgeneridade guerreira', personagens que viveram sempre que puderam como homens e que foram à guerra (MAIA, 2018, p. 99).

Assim seria possível a leitura de uma "transgeneridade guerreira" em Diadorim. A visão de Riobaldo do menino na travessia do rio São Francisco reforçaria a face transgênero de Diadorim: “Aí pois, de repente, vi um menino, [...] pitando cigarro. Menino mocinho, pouco menos do que eu, ou devia de regular minha idade." (ROSA, 2015, p. 94). Maia (2018) coloca em suspensão os estudos literários sobre a tipologia em questão, pois entende que estes estudos trataram o gênero de forma exclusivamente biológica e binária: "reduzindo todas as diversas experiências das donzelas-guerreiras à

\footnotetext{
12 Um exemplo que evidencia a pluralidade de gêneros no interior do Brasil, bem como suas vulnerabilidades, é o trabalho realizado pelos jornalistas Gustavo Werneck, Alexandre Guzanshe e de Fred Bottrel do jornal Estado de Minas, onde relatam histórias reais de pessoas LGBTQI+, ou "anônimos Diadorins" no sertão mineiro em busca da própria identidade. Disponível em: http://especiais.em.com.br/travessia. Acesso em: 11 abr. 2020.
} 


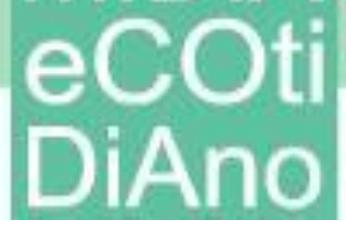

lei paterna" (p. 100). Para o autor, a crítica tem "invisibilizado os corpos e as vidas literárias" (p. 100). A mesma inferência pode ser transportada para as diversas tentativas de tradução imagética ${ }^{13}$ de Diadorim (muitas delas são problemáticas sob o nosso ponto de vista), sobretudo no audiovisual, que ganharam forma com as atrizes Sônia Clara e Bruna Lombardi, e nas quais se reforçou a imagem da mulher objeto sob uma perspectiva binária, desconsiderando as possibilidades de trânsito de gêneros e garantindo assim que a ordem da sexualidade não fosse ultrapassada, configurando-se numa "representação tranquilizadora" (MAIA, 2018).

Figura 1 - Atriz Sônia Clara no papel de

Diadorim. Filme Grande Sertão: Veredas, 1965

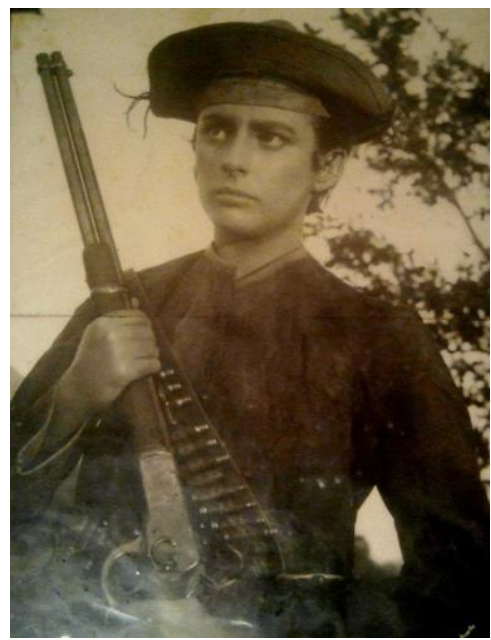

Fonte: Disponível em: shorturl.at/afj12. Acesso em: 09 abr. 2020.
Figura 2 - Bruna Lombardi no papel de Diadorim. Minissérie Grande Sertão, 1985

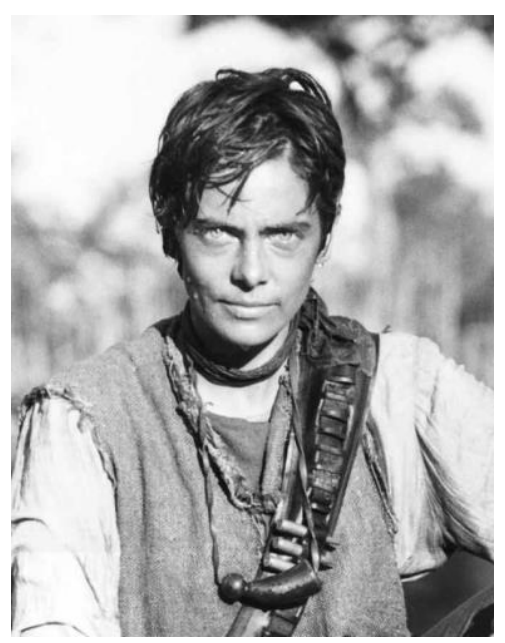

Fonte: Disponível em: http://tiny.cc/uhpdpz. Acesso em: 09 abr. 2020.

Para Laísa Bastos (2016) é possível pensar Diadorim como um homem trans, uma vez que seria possível ver nele uma masculinidade partilhada com a de Riobaldo. Bastos considera o fato de Diadorim se vestir de menino desde a adolescência. Tal abordagem ancora-se na noção de performatividade de Judith Butler, cujos comportamentos são seguidos mediante os padrões que sustentam as normas de gênero,

\footnotetext{
${ }^{13} \mathrm{O}$ que chamamos de tradução imagética são as diversas tentativas de transportar a imagem escrita para a imagem visual e plástica.
} 
heteronormativas, portanto. Para Butler: “[...] é por meio da repetição estilizada de atos corporais, gestos e movimentos específicos que o efeito do gênero é criado como ‘temporalidade social'” (BUTLER, 2014, p. 242). A nosso ver, não há dúvidas de que o Grande sertão: veredas é um livro que aborda o universo masculino, onde impera a dominação fálica, mas o efeito dessa violência de gênero dificilmente ganha relevo pela crítica. Santiago sublinha o caráter fálico da obra, simbolizados pelo rio São Francisco “- que de tão grande se comparece — parece é um pau grosso, em pé, enorme...” (p. 492), e a palmeira buriti, neste sentido o leitor estaria diante uma verdadeira "briga de espadas":

No sertão de Guimarães Rosa transcorre uma 'luta' de gender (masculinidade versus masculino). A pose sexual de Diadorim pelo jagunço Riobaldo - ou a experiência no sertão de uma "confraria de espadas" (para citar Rubens Fonseca), de que são membros metafóricos tanto o ereto rio São Francisco quanto o fálico buriti-grande - é 'o problema' que põe em luta as ideias conservadoras da sociedade patriarcal se vistas da perspectiva das conquistas sociais atuais no plano da opção sexual diferenciada (SANTIAGO, 2017, p. 38).

\section{"Diadorim Sou Eu"}

Se já foi difícil para a crítica encarar os diversos temas-tabus ou "saberes polêmicos" de Grande sertão, o que dizer da revelação biográfica feita por Guimarães Rosa a Afonso Arinos de Mello Franco, momentos antes da posse na ABL?

Dias antes da posse, uma noite, [Rosa] foi me visitar. Trazia-me uns dados novos, para ver se eu os queria aproveitar. E de repente, com o dedo em riste diante dos lábios, e depois de olhar em volta, para certificar-se de que estávamos sós, ele fez esta confidência: ' $O$ Diadorim do Grande sertão sou eu. Mas isto é só para você' (ARINOS apud MONTELLO, 1998, p. 186).

Esta passagem, presente nos diários de Montello (1998), fato da memória pessoal de Afonso Arinos, assinala um conflito de gênero presente no próprio Guimarães Rosa. Reservado, discreto e quieto, Rosa procurava não dar entrevistas, quase não levava ninguém à sua casa, acreditava que sua profissão de diplomata exigia dele equidistância de jornalistas, críticos e grupos literários. Justamente por isso, devemos nos limitar a dizer que os aspectos fisionômicos que ligavam Guimarães Rosa a Diadorim estavam primeiro 


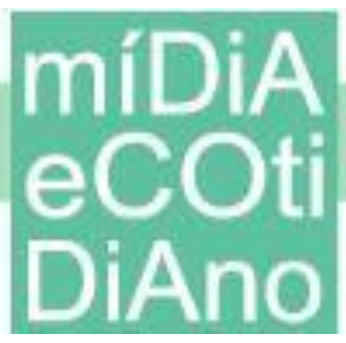

em ambos possuírem olhos verdes, trejeitos e gestos efeminados. O jeito enigmático, característica essencial em Diadorim também não se distancia do discurso quase que impenetrável do autor. A exemplo da sua entrevista concedida ao jornalista Günter Lorenz, Rosa parece esconder algum segredo, numa espécie de "fala neblina".

Para retomar a noção fantasmática lançada no início deste trabalho, tanto criador quanto criatura (Rosa-Diadorim) podem ser vistos como phasmes — do grego phasma, que significa forma, aparição, visão, fantasma, e por consequência presságio. Na vida animal, os phasmes são pequenos animais estranhos que se mesclam na natureza - o bicho de pau, por exemplo. São bichos que estão presentes, mas se fazem imperceptíveis. Para Georges Didi-Huberman “os phasmas fazem de seu próprio corpo a decoração, onde eles [mesmos] se escondem ${ }^{14}$ ", (DIDI-HUBERMAN, 1998, p. 17).

O crítico uruguaio e editor de literatura latino-americana Emir Rodrigues Monegal relata o encontro com Guimarães Rosa em viagem para Nova York e a destreza do escritor ao se "camuflar" no meio dos fotógrafos. Monegal completa: “Temos que trabalhar a favor das limitações' me disse Guimarães Rosa, com um sorriso que refletia seu sentido irônico, complexo da vida" (MONEGAL, 1983, p. 51)

Mesmo que a hipótese de conflito de gênero em Guimarães Rosa seja encarada como absurda para o pensamento reacionário, é curioso notar o esforço que se faz para a manutenção da sua intocável imagem de gênio literário, efeito do estereótipo que assegura o conservadorismo da norma heterossexual: pai adorável, bom esposo, incansável trabalhador, verdadeiro homem de virtudes. Ora, a grandiosidade do homem e do artista deveria ser a consciência da sua humanidade, isto é, a consciência da sua animalidade e limitação. A esse respeito a expressão “existe é homem humano” (ROSA, 2015, p. 492) consegue dar conta da concepção ordinária da vida.

Aceitar a afirmação de Guimarães Rosa é a condição para a possibilidade de misturar os opostos, múltipla de significados e quase infinita de interpretação. Poderíamos imaginar que, fora da crítica conservadora brasileira, tal pressuposto seria campo fértil de análise, como ocorreu com Gustave Flaubert, na suposta declaração

\footnotetext{
14 "Le phasme a fait de son prope corps le décor où il se cache" (livre tradução dos autores).
} 
"Madame Bovary c'est moi"15. Diversas leituras investem na falibilidade humana de "gênios" artísticos. Além de Flaubert, pensamos em Leonardo da Vinci — investigado por Freud no clássico texto "Uma lembrança de infância", de 1910.

O problema é que o mesmo pensamento que normaliza e consente que uma mulher possa se esconder por anos o seu sexo, aceitando tudo que essa violência de gênero pode acarretar, é o mesmo pensamento que nega um grande nome da literatura brasileira se identificar, ou mesmo interessar-se pelos papéis femininos; orientar-se na direção e na identificação de uma visão de mundo sob o prisma da mulher. Tudo isso é um campo por demais fértil e digno de atenção.

Ainda sobre as polêmicas declarações de Guimarães Rosa, o mesmo vale para os seus reais interesses pelo satanismo e a feitiçaria popular. Em sua biblioteca, conservada no Instituto de Estudos Brasileiros (IEB), na USP, seu volume Satan, de 666 páginas, comprado em Paris, em 1948 (Ed. Desclée de Brouwer), foi atentamente lido, estudado e rabiscado. Costuma-se dar mais atenção aos diferentes nomes que Rosa encontrou para o "Capiroto", do que questionar o real interesse do mineiro pelo tema. Em uma entrevista dada a Ascendino Leite, em 1946, para $O$ Jornal, logo após a publicação de Sagarana, Rosa diz não só se interessar pelo tema do diabo como atesta claramente: "Já fiz pequenos pactos, provisórios, com o dito. Se eu tivesse morrido três meses depois, estava frito..."16. Além disso, a nosso ver, o problema da escritura “mediúnica” de Grande sertão, é outro ponto silenciado, apesar da fartura de hipóteses neste sentido. Apenas para citar uma delas, em matéria escrita pelo jornalista (e amigo íntimo) Franklin de Oliveira para a revista $O$ Cruzeiro, publicada no exato mês de lançamento de Grande sertão:

\footnotetext{
15 Flaubert foi acusado de ofensa à moral com a publicação de sua obra homônima Madame Bovary, e declarou, dias antes da sentença de absolvição, "Emma Bovary c'est moi". A declaração ainda levanta debates controversos, no entanto, tornou-se uma das citações mais célebres do autor.

16 "Pacto provisório" é uma expressão utilizada no oeste da Bahia, Minas, Goiás e parte de São Paulo para designar um pacto que se faz com o Diabo sem que seja negociada a alma, mas acordado outro pagamento: um bezerro, um galo, um boi, uma canção ou um livro, por exemplo. O pacto tem a duração de três meses. Caso o pactário morra nesse tempo sua alma passará por óbvio para o Diabo. A tradição popular assevera que o Diabo tenta de todas as formas matar o pactário neste tempo para ficar com sua alma, daí a expressão utilizada por Rosa: "se eu tivesse morrido três meses depois, estava frito". A tradição popular também construiu narrativas sobre as formas de escapar do Diabo durante esses meses. As formas de invocação do Diabo utilizadas por Rosa em Grande sertão: veredas estão de acordo com aquelas descritas nos tratados medievais, nos estudos de demonologia e na literatura especializada.
} 


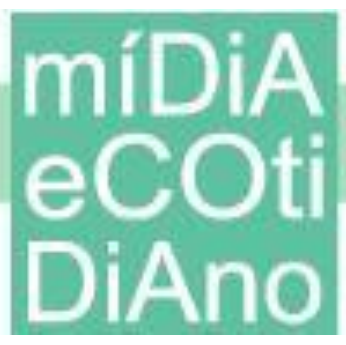

veredas, em julho de 1956, Rosa disse: "Quando escrevo, é como se fosse tomado pelos caboclos de Minas. Deixo, então, que eles 'baixem’ e me entrego”.

\section{A crítica jornalística em Grande sertão: veredas}

As críticas da Folha de S. Paulo, O Estadão e Metrópoles preferem trazer comparações com clássicos da literatura mundial: J. W. Goethe ${ }^{17}$, Thomas Mann ${ }^{18}$, James Joyce $^{19}$ e Lev Tolstói ${ }^{20}$, afagados pela corrente comparatista cujo ponto de paridade é a literatura europeia. No texto da Folha, por exemplo, Berthold Zilly enxerga Grande sertão mediante três pontos: 1) "revelação do potencial expressivo da língua portuguesa", como inovação na linguagem e da forma narrativa; 2) como uma interpretação do Brasil, pela contraposição de um Brasil arcaico versus moderno, e 3) como "laboratório da condição humana". Em nenhum desses pontos, a "aberração inquietante, perturbadora e solitária", a que se refere Santiago (2017, p. 24), surge como preocupação temática. No trecho: "uma moderna representação épica de um cosmos rural, de envergadura tolstoiana", Zilly assume um posicionamento hierárquico e diacrônico, próprio das análises comparatistas, e situa a obra em relação a um antes "superior". Nota-se que esse é um artifício recorrente quando se pretende atribuir valor ao texto literário, desviandose do trabalho de enfrentamento do próprio corpo da obra, sobretudo quando se trata de um corpo indócil e brutal. A crítica de Zilly assinala aspectos ideais da condição humana, organizados numa série de questionamentos que o crítico descreve como "problemas existenciais", dos quais "vida boa, digna, feliz" e "convívio civilizado, justo em harmonia com a natureza" são pontos enfrentados pelo "herói épico" de Grande sertão.

Na crítica de Lúcio Flávio, do portal Metrópoles, os pontos ressaltados foram: 1) Apresentação do contexto com a descrição da nova edição da Cia. das Letras, situando o livro num "cenário medieval, onde reina a injustiça"; 2) Caracterização da obra como

17 J. W. Goethe (1749-1832), autor do drama trágico Fausto, foi a matriz mais consensual nos estudos comparados que dão atenção ao pacto de Riobaldo.

18 Thomas Mann (1875-1955), romancista, ensaísta e crítico social, recebeu o Nobel de Literatura em 1929 e, em 1947 publicou seu romance Doutor Fausto.

${ }^{19}$ Para o Jornal Metrópoles, há no Grande sertão: veredas "[e]lementos que o levam a ser comparado ao irlandês James Joyce, autor de obras como Ulisses (1922) e Finnegans Wake (1939)".

${ }^{20}$ Lev Tolstói (1828-1910), escritor russo, foi também ensaísta e filósofo, autor dos romances Guerra e Paz e Ana Karenina. 


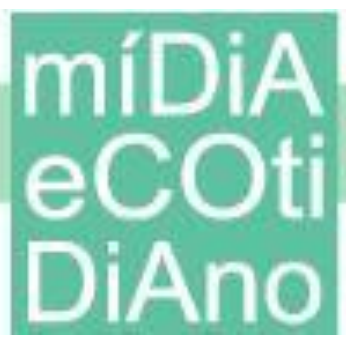

“difícil, mas essencial”, resultado da experiência empírica do escritor e médico, que lhe permitiu tecer uma narrativa de "amor, alegria, ambição, insatisfação, solidão, dor, medo e morte..."; 3) Destaque para a "invenção de uma nova língua e de um universo único", com aspectos da fauna e flora, identidade regional singular, contexto da diversidade cultural e socioambiental do Brasil. Lúcio Flávio descreve o Grande sertão: veredas como obra sui generis, sem fazer nenhuma referência a Diadorim. Na mesma via de Berthold Zilly, a crítica de Lúcio Flávio reitera a perspectiva europeia ao abordar, mesmo que apressadamente, a temática do satanismo: "relatos de lutas [...] se fundem com tramas de amor e pactos satânicos, numa releitura bem original do mito de Fausto, do alemão Göethe”. No entanto, é espantosa a quantidade de nomes que Guimarães Rosa encontra para se dirigir ao diabo: cento e nove codinomes, para sermos mais exatos. Alguns com diapasão tão brasileiros que merecem uma atenção, como "xu”, que nos parece remeter a entidade afro-brasileira Exú. O que dizer do trecho: "E ele, o Reinaldo, era tão galhardo garboso, tão governador, assim no sistema pelintra [...]” (ROSA, 2015, p. 131)? Ademais, o adjetivo "original" não rompe com a lógica emulativa, uma vez que a "originalidade" assinalada não é distinguida. $\mathrm{O}$ crítico atém-se aos relatos biográficos do autor mineiro, remontando à imagem de médico, bom filho e funcionário do Itamaraty, sinais associativos de uma biografia virtuosa para uma obra heroica. Por fim, a crítica de Lúcio Flávio exime-se das temáticas abjetas, mesmo diante da qualificação sui generis.

Na crítica de Milton Hatoum, do Estadão, a "linguagem inovadora" do romance é assinalada logo no exórdio da redação, seguido dos seguintes pontos: 1) Apresentação da estratégia narrativa como "fluxo de consciência" acompanhado da menção a diversos trechos do romance. Hatoum refere-se à história de amor entre "os jagunços Riobaldo e Reinaldo (Diadorim)" como sendo, "talvez, a mais transgressora da obra". No entanto, indica chaves de leitura que conduzem o leitor à revelação de Diadorim jagunço como mulher, justificado no argumento do ciúme entre Diadorim e Otacília na Fazenda Santa Catarina. A descrição, acompanhada de imagens telúricas, é um convite ao sublime da obra: “[...], uma fazenda 'perto do céu' [...]. O céu é citado três vezes nessa primavera, quando no ar dos gerais há borboletas brancas, pássaros, pombas no bebedouro e as "verdadeiras, altas, cruzando do mato"'. A leitura dos pactos, tanto de Hermógenes como de Riobaldo, é feita do ponto de vista metafísico; 2) Aspectos da linguagem e do lirismo 
de Guimarães Rosa são demonstrações pela "virtuosidade [...] na construção dos personagens e na arquitetura do romance"; 3) No desfecho, a tese do Grande sertão: veredas como laboratório da condição humana reaparece: “A obra-prima de Guimarães Rosa é uma sondagem profunda da alma humana." Dos três recortes, o que melhor consegue, a nosso ver, atacar as contradições do livro é Milton Hatoum: “Ao mesmo tempo, o romance remete ao atraso histórico, à extrema violência e à miséria do Brasil", numa comparação entre o passado do livro e a atualidade do Brasil.

No entanto, ao comparar a temática do pacto com a obra de Thomas Mann, Hatoum marca, logo de início, sua leitura etnocêntrica. Com isso, o crítico lança o imaginário do pacto satânico para uma realidade distante, diferindo do movimento narrativo do Grande sertão, que tende à proximidade. "Quem muito se evita, se convive. Sentença num Aristides — o que existe no buritizal", sujeito descrito por Riobaldo que, por onde anda, "escuta um chorinho, atrás, e uma vozinha que avisando: — 'Eu já vou! Eu já vou!...' - que é o capiroto, o que-diga..." (ROSA, 2015, p. 20) ou, o caso do Jisé Simpilício, "quem qualquer daqui jura ele tem um capeta em casa, miúdo satanazim" (ROSA, 2015, p. 20). Os grifos nossos denotam essa marca de proximidade. No caso de Diadorim, a crítica de Milton Hatoum opta por revelar tanto da morte quanto do sexo da personagem. A categorização do sexo de Diadorim por Hatoum como "verdadeira identidade" insere-se numa ótica heteronormativa compulsória, ao mesmo tempo que levanta outra problemática pouco explorada, a de que o desfecho de Grande sertão: veredas pode ser lido como uma indulgência ao "pecado" da pederastia, pois redime Riobaldo da culpa e do desejo proibido, oferecendo, assim, um perdão heterossexual.

Por fim, vale destacar que os três recortes jornalísticos foram elaborados por homens cisgêneros, garantindo assim a permanência de uma visão de heteronormativa, não diferente da tradição crítica literária brasileira, seja acadêmica ou jornalística. $O$ mesmo serve para os apontamentos de ordem comparatistas, elaborados pelos críticos como base em princípios etnocêntricos, definidos por Santiago pelas noções de "fonte e influência", reforço dos aspectos dependente, repetitivo e redundante das literaturas periféricas, de modo a garantir a voz da crítica consolidada. Para Santiago: "O levantamento desses aspectos duplicadores (útil, sem dúvida, mas etnocêntrico) visa a 


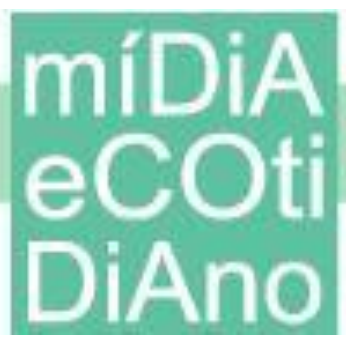

sublinhar o percurso todo-poderoso da produção dominante nas áreas periféricas por ela definidas e configuradas" (SANTIAGO, 1982, p. 20).

Do modo como percebemos, tais análises contribuem para a rarefação dos temas polêmicos no livro. Em entrevista concedida à revista de sociologia da USP, Davi Arrigucci Jr. (2011) notou certa falta de rigor e empobrecimento da crítica literária na imprensa jornalística: “as resenhas se resumem a notícias de livros que saíram, à indicação do movimento das editoras, mas não há crítica no sentido de análise e avaliação das obras" (ARRIGUCCI JR. em entrevista a JACKSON; PINHEIRO FILHO; SORÁ, 2011, p. 181).

No entanto, há dissensos. Manuel Bandeira, em carta de março de 1957 a Guimarães Rosa: “[...] andaram dizendo que você tinha inventado uma língua nova e eu não gosto de língua inventada [...]. Vai-se ver, não é língua nova nenhuma a do Riobaldo" (BANDEIRA, 1983, p. 512). Manuel Bandeira não só desgosta da ideia de uma língua nova como do desfecho do romance: "E o caso de Diadorim, seria mesmo possível? Você é dos gerais, você é que sabe. Mas eu tive a minha decepção quando se descobre que Diadorim era mulher. Honni soit que mal y pense, eu preferia Diadorim homem até o fim" (BANDEIRA, 1983, p. 512).

Bandeira admite a relação entre dois homens no sertão brasileiro. Envergonhese aquele que vê maldade entre a companhia de dois cavaleiros. Duas interpretações são, portanto, possíveis: ou Bandeira não vê maldade na amizade entre Riobaldo e Diadorim e ignora as passagens em que Riobaldo se inquieta com o desejo sexual que sente pelo amigo, ou gostaria de ter lido uma história de amor entre dois guerreiros, ambientada no interior atrasado e machista do Brasil. Para Ashley Brock (2018), no seu artigo The Queer Temporality of Grande sertão: vereda, Riobaldo não seria o único seduzir-se por outro homem, o leitor também estaria seduzido por essa espécie de “queer love story” (BROCK, 2018, p. 192).

A revista francesa Le nouvel observateur ${ }^{21}$, na ocasião da publicação da segunda edição do livro no país, em 1991, publicou a crítica de Dominique Fernandez, escritor e

\footnotetext{
${ }^{21}$ Le nouvel Observateur, revista francesa originada do periódico L'Observateur politique, économique et littéraire, foi criado em 1950 com a colaboração de Jean-Paul Sartre.
} 
investigador do universo homossexual. Fernandez não demorou em sublinhar o enfoque homossexual do romance "Grande sertão: veredas tem, desde já, seu lugar marcado na literatura homossexual, como um clássico da clandestinidade amorosa e da paixão casta, elevado à potência do continente americano"22 (1991, p. 99).

\section{Considerações finais}

Esta investigação ocupou-se com a crítica jornalística atual, suscitada pelo relançamento da obra. Ao mesmo tempo, articulamos uma série de documentos, publicações e declarações que não ganharam espaço nos textos jornalísticos. Nota-se, por exemplo, que a crítica jornalística não se ocupou em revisar os debates acadêmicos mais recentes, que exploram a abordagem de gênero, por exemplo. Optaram por manter a voz do cânone, postura que enfraquece o trabalho crítico e alimenta o impulso de preservar o "animal enjaulado".

A nosso ver, a tentativa da crítica jornalística, sobretudo aquela que busca tanto edulcorar o enredo e as mensagens de Grande sertão: veredas assim como ordenar os elementos caóticos, confusos, desordenados, da narrativa adotada por Riobaldo, aproxima-se mais de uma crítica propriamente publicitária do que jornalística. Do ponto de vista de Davi Arrigucci Jr. (2011), ao afirmar que as "resenhas se resumem a notícias de livros", sustentamos o nosso argumento de que a crítica atua mais no fomento ao marketing do livro do que se comprometendo com a realidade literária.

Assumir que um cânone da literatura brasileira esteja eivado do nefasto, da pederastia, da maldade e da abjeção é um posicionamento de risco e implica indicar sobretudo nos tempos do Brasil atual - que uma de suas obras mestras, evoque a arte maldita. Além de destacar o aspecto ambíguo de Guimarães Rosa mediado pelo personagem Diadorim, concordamos com Santiago para quem o aspecto selvagem do Grande sertão: veredas apresenta-se ao leitor mediante sua dimensão indomável e feroz. Na visão de um pensamento colonial, a hipótese possível é a da dominação: domesticar o

\footnotetext{
22 “Diadorim a sa place d'ores et déjà marquée dans la littérature homosexuelle, comme un classique de la clandestinité amoureuse et de la passion chaste, hissé à la puissance du continent américain" (livre tradução dos autores).
} 
estranho, a besta, e adaptá-la aos padrões dominantes. Essa, parece ser a postura recorrente no tocante à crítica jornalística brasileira em relação ao livro.

\section{Referências}

BALDER, Daniel. El narrador deslocado y desplumado: los deseos de Riobaldo en Grande sertão: Veredas". Revista de la Facultad de filosofia y humanidades, Universidade de Chile, 1999.

BANDEIRA, Manuel. Poesia completa e prosa. Rio de Janeiro: Nova Aguilar, 1983.

BASTOS, Marra de Paula C. Diadorim Trans? Performance, Gênero e Sexualidade em Grande sertão: Veredas. In: SIMPÓSIO NACIONAL DE PÓS-GRADUAÇÃO EM ESTUDOS DA LINGUAGEM, 1. Anais do 14 ${ }^{\text {a }}$ Semana de Letras da UFOP, Mariana, MG, p. 330-342, 2016.

BROCK, Ashley. The Queer Temporality of Grande Sertão: veredas. Chasqui - Revista de literatura latino-americana. n. 47.2, p. 190-203, novembro de 2018.

BUTLER, Judith. Problemas de gênero: feminismo e subversão da identidade. Tradução de Renato Aguiar. Rio de Janeiro: Civilização Brasileira, 2014.

CABRAL, Mauro. La paradoja transgénero. Boletín Electrónico del Proyecto Sexualidades, salud y derechos humanos en América Latina, n. ${ }^{\circ}$ 18, p. 97-104, 2006.

DIDI-HUBERMAN, Georges. Phasmes: Essais sur l'Apparition, 1. Paris: Éditions de Minuit, 1998.

FANON, Franz. Os condenados da terra. Juiz de Fora: UFJF, 2018.

FERNANDEZ, Dominique. Le Sertão des desirs. Le Nouvel Observateur. 7-13, p. 99 fev. 1991.

FLÁVIO, Lúcio. Grande Sertão: Veredas ganha reedição de luxo pela Cia das Letras.

Metrópoles. 25 fev. 2019. Disponível em: http://tiny.cc/g4vdpz. Acesso em: 06 abr. 2020.

FREUD, Sigmund. O infamiliar [Das Unheimliche]. Tradução de Ernani Chaves e Pedro Heliodoro Tavares. São Paulo: Autêntica, 2019.

GALVÃO, Walnice Nogueira. As formas do falso: um estudo sobre a ambiguidades no Grande Sertão: Veredas. São Paulo: Perspectiva, 1986.

HALBERSTAM, Jack. Masculinidad Femenina, Barcelona: Egales, 2008.

HATOUM, Milton. Nova edição de 'Grande Sertão: Veredas' deve atrair e formar novos leitores. O estado de São Paulo. 19 fev. 2019. Disponível em: http://tiny.cc/88vdpz. Acesso em: 06 abr. 2020.

JACKSON, Luiz; PINHEIRO FILHO, Fernando; SORÁ, Gustavo: Entrevista com Davi Arrigucci Jr. Tempo Social, revista de sociologia da USP, v. 23, n. 2, p. 163-188, 2011.

KRISTEVA, Julia. Pouvoirs de l'horreur. Essai sur l'eabjection. Paris: Éditions du Seuil, 1980. 
KRISTEVA, Julia. "Sobre la abyección"; "De que tener miedo". In: Poderes de la perversión. 5. ed. Buenos Aires: Siglo XXI Editores Argentina S.A., 2004.

MAIA, Helder Thiago. Transgressões Canônicas: Queerizando a Donzela-Guerreira. Cadernos de literatura comparada. Instituto de Literatura Comparada Margarida Losa, n. 39, p. 91-108, $\operatorname{dez} / 2018$.

MONEGAL, Emir Rodríguez. Em busca de Guimarães Rosa. In: COUTINHO, Eduardo F. Guimarães Rosa. Rio de Janeiro/Brasília: INL, 1983. (Col. Fortuna Crítica, 6). p. 47-61.

MONTELLO, Josué. Diário Completo, v. 2. Rio de Janeiro: Nova Aguilar, 1998.

MORAES, Vanessa Danielle de. Passagens abjetas. Florianópolis: Papa-Livros, 2011.

OLIVEIRA, Franklin. Coluna "Sete Dias". Revista O Cruzeiro. 15 jul. 1956.

ROSA, João Guimarães. Grande sertão: veredas. Rio de Janeiro: Nova Fronteira, 2015.

SANTIAGO, Silviano. Vale quanto pesa. Rio de Janeiro: Paz e Terra, 1982.

SANTIAGO, Silviano. Genealogia da Ferocidade: Ensaio sobre Grande Sertão: Veredas, de Guimarães Rosa. Recife: Cepe, 2017.

SLOTERDIJK, Peter. Crítica da razão cínica. Tradução de Marco Casanova, Paulo Soethe et al. São Paulo: Estação Liberdade, 2012.

SPARGO, Tamsin, Foucault e a teoria queer: seguido de Ágape e êxtase: orientações pósseculares. Tradução de Heci Regina Candiani. Belo Horizonte: Ausência, 2017.

SUSSEKIND, Flora. Rodapés, tratados e ensaios: a formação da crítica brasileira moderna. In: SUSSEKIND, Flora. Papéis colados. Rio de Janeiro: UFRJ, 1993.

TIBURI, Marcia. Diadorim: Biopolítica e gênero na metafísica do Sertão. Estudos Feministas, Florianópolis, v. 21, n.1, p. 191-207, jan.-abr./2013.

WERNECK, Gustavo; GUZANSHE, Alexandre; BOTTREL, Fred. Especial travessia. Estado de Minas, Disponível em: http://especiais.em.com.br/travessia. Acesso em: 11 abr. 2020.

VILALVA, Walnice M. Riobaldo/Diadorim e o tema da homossexualidade. Revista Cerrados, v 17, n. 25, p. 233-243, 2008.

ZILLY, Berthold. Sertão de Guimarães Rosa pode ser visto como laboratório da condição humana. Folha de S. Paulo, Seção Ilustrada. 10 fev. 2019. Disponível em: shorturl.at/AMW78. Acesso em: 06 abr. 2020. 